\title{
Architecture of intereruptive and syneruptive facies in an Andean Quaternary palaeovalley: the Huarenchenque Formation, western Argentina
}

\author{
*Luis A. Spalletti'1, Ferrán Colombo Piñol ${ }^{2}$
}

\author{
${ }^{1}$ Centro de Investigaciones Geológicas, Calle 1 N 644, B1900TAC La Plata, Argentina. \\ luis.spalletti@gmail.com; spalle@cig.museo.unlp.edu.ar \\ ${ }^{2}$ Facultat de Geologia, Universitat de Barcelona, C/Martí i Franqués, s/n, 08028 Barcelona, España. \\ ferran.colombo@gmail.com \\ *Corresponding autor: luis.spalletti@gmail.com; spalle@cig.museo.unlp.edu.ar
}

\begin{abstract}
The Huarenchenque Formation is a volcano sedimentary unit deposited to the east of the Plio-Quaternary Andean Magmatic Arc. In order to define depositional settings, two lithofacies associations (fluvial and pyroclastic) were defined. The fluvial facies association is composed of polymictic conglomerates with the predominance of basaltdominated clasts, coarse- medium-grained conglomeratic sandstones and medium- to coarse-grained sandstones. These deposits occur as stacked or single bodies, display both sheet and channelized geometries, and contain a range of internal sedimentary structures, such as planar, low angle stratification and cross-bedding. This facies association is interpreted as the deposit of a multichannel fluvial system characterized by high bed load, steep gradient and non-cohesive bank materials. Facies and architecture of the fluvial deposits are the result of high bank full discharge related to rapid deglaciation of the Andean Last Glacial Maximum. The pyroclastic facies association is characterized by lapilli and ash tuffs deposited from air fall, pyroclastic density current, and density stratified surge mechanisms. In the Huarenchenque Formation the fluvial and the pyroclastic facies associations show a clear physical separation, suggesting that sedimentation occurred in two distinct (intereruptive and syneruptive) phases. During the long-lived intereruptive phases the sedimentary record corresponds mainly to the deposits of the gravelly braided fluvial system, whereas during syneruptive phases the fluvial valley was almost entirely occupied by primary pyroclastic deposits related to high-explosive episodes of the neighbor Andean strato-volcanoes.

Although most of the cross-bedded sandstones and conglomerate sandstones are rich in basaltic fragments, some strata are composed almost entirely of pumiceous fragments, while in others there is a marked alternation between "basalt" and "pumiceous" foresets. These attributes reflect the preservation of intrabasinal pyroclastic fragments and allow suggest that: i. explosive volcanic events could be more frequent than reflected by the pyroclastic deposits themselves; ii. syneruptive pyroclastic materials could be eroded (even eliminated) by the fluvial system; iii. contributions of primary pyroclastic material persisted during intereruptive (fluvial-dominated) phases.
\end{abstract}

Keywords: Bed load fluvial systems, Pyroclastic processes, Intereruptive, Syneruptive, Quaternary, Argentina.

RESUMEN. Arquitectura de las facies intereruptivas y sineruptivas en un paleovalle andino del Cuaternario: la Formación Huarenchenque en el oeste de Argentina. La Formación Huarenchenque es una unidad volcano-sedimentaria depositada al este del arco magmático andino plio-cuaternario. Con la finalidad de establecer los sistemas de acumulación se definieron dos asociaciones de litofacies: fluvial y piroclástica. La primera está compuesta de conglomerados polimícticos con predominio de clastos basálticos, areniscas conglomerádicas, y areniscas gruesas a medianas. Estos depósitos aparecen como cuerpos complejos (multiepisódicos) o simples, desarrollan geometrías mantiformes y acanaladas, y muestran un amplio rango de estructuras primarias, tales como capas planares, de bajo ángulo y entrecruzadas. Esta asociación de facies se asigna a un sistema fluvial multicanalizado que se caracteriza por una alta proporción de material transportado como carga de lecho en condiciones de alto gradiente y con bancos no cohesivos. Las facies y la arquitectura de los depósitos fluviales se considera el producto de una importante descarga relacionada con la rápida deglaciación del Último 
Máximo Glacial Andino. La asociación de facies piroclástica está constituida por lapillitas y tobas vítreas depositadas por procesos de caída piroclástica, flujos piroclásticos densos y oleadas piroclásticas de alta energía. En la Formación Huarenchenque las asociaciones de facies fluvial y piroclástica muestran una clara separación física, lo que permite inferir la existencia de dos distintas fases: intereruptiva y sineruptiva. En las fases intereruptivas, de larga duración, el registro sedimentario corresponde esencialmente a los depósitos del sistema fluvial entrelazado gravoso, mientras que durante las fases sineruptivas el valle fluvial fue casi enteramente ocupado por depósitos piroclásticos primarios, relacionados con episodios volcánicos de alta explosividad acaecidos en los vecinos estrato-volcanes de la región andina. Si bien la mayoría de las capas entrecruzadas de areniscas y areniscas conglomerádicas son ricas en fragmentos basálticos, algunos estratos están compuestos casi enteramente por fragmentos pumíceos, en tanto que en otros se aprecia una marcada alternancia entre capas frontales "basálticas" y "pumíceas". Estos atributos reflejan la preservación de componentes intracuencales de naturaleza piroclástica y permiten sugerir que: i. los eventos volcánicos explosivos pudieron ser más frecuentes que lo que reflejan los propios depósitos piroclásticos; ii. materiales piroclásticos sineruptivos pudieron ser erosionados (hasta eliminados) por el sistema fluvial; iii. contemporáneamente con el dominio de condiciones fluviales se produjeron aportes de material piroclástico primario.

Palabras clave: Sistemas fluviales de carga de lecho, Procesos piroclásticos, Intereruptivo, Sineruptivo, Cuaternario, Argentina.

\section{Introduction}

The episodic nature of volcanic eruptions may profoundly impinge on sedimentary environments, and the influence of volcanism on the sedimentary record has been addressed in several classic studies (Smith, 1987, 1991; Waresback and Turbeville, 1990). Specially, volcanic activity always has a large impact on fluvial systems, and a growing number of studies document the influence of volcanism in modifying the sedimentation pattern of these settings (Cole and Ridgway, 1993; Palmer, 1997; Palmer and Shawkey, 1997; Segschneider et al., 2002; Kataoka et al., 2009; Manville et al., 2009; Sohn et al., 2013). Several authors have pointed out that sedimentary processes operating within an active volcanic terrain are different compared with those of non-volcanic settings and cannot be adequately explained by the existing or "background" alluvial facies models (Smith, 1987; Khalaf, 2012). Comprehensive models of volcanism and fluvial sedimentation are, however, still beyond the reach because of the difficulty of placing independent constraints on all possible controlling variables from the stratigraphic record.

The lithofacies around a subaerial volcanic edifice can be classified as syneruptive and intereruptive lithofacies based on the differences in constituent sediments and depositional features (Smith, 1991). Based on the concept of syneruptive and intereruptive lithofacies, numerous investigations have been conducted in order to reveal how volcanic eruptions affect depositional environments and how volcanic impacts change with time (Kuenzi et al., 1979; Palmer et al., 1993; Bahk and Chough, 1996; Major et al., 1996;
Pierson et al., 1996; Valentine et al., 1998; Kataoka et al., 2009; Németh et al., 2009; Pierson et al., 2011). During explosive eruptions, a volcanic edifice and surrounding areas are mantled by unconsolidated and fine-grained volcaniclastic sediments deposited by pyroclastic density currents and fallout from eruption columns (Gihm and Hwang, 2014). In contrast, during an intereruptive period, normal fluvial processes are dominant due to gradual decrease in available coeval volcaniclastic contribution, and intereruptive lithofacies are commonly confined in and around the channels, accompanied with incision of the syneruptive lithofacies (Gihm and Hwang, 2014).

Along the Andean Cordillera active volcanoes occur when the angle of subduction is relatively steep. Between $37^{\circ} 30^{\prime} \mathrm{S}$ and $38^{\circ} 30^{\prime} \mathrm{S}$, the Caviahue caldera in the Copahue volcano complex (CAC, Melnick et al., 2006) represents the Plio-Quaternary subduction-related arc volcanism, characterized by polymodal emissions dominated by andesitic-dacitic lavas (Hildreth and Moorbath, 1988). The CAC is limited to the east by the Loncopue trough (Ramos, 1978), a Quaternary tectonic depression filled with backarc monogenetic alkaline basalts (Muñoz and Stern, 1988; Kay et al., 2006). The uplift of the Andes since the Miocene and the construction of Neogene volcanic edifices played a role in the reorganization of drainage patterns. The eastern slopes of the Andean Cordillera were drained by fluvial systems, and one of these systems is represented by the Pleistocene Huarenchenque Formation, which was accumulated towards the eastern sector of the Loncopue trough (Fig. 1). The present work seeks to examine the sedimentology and stratigraphic architecture of the 


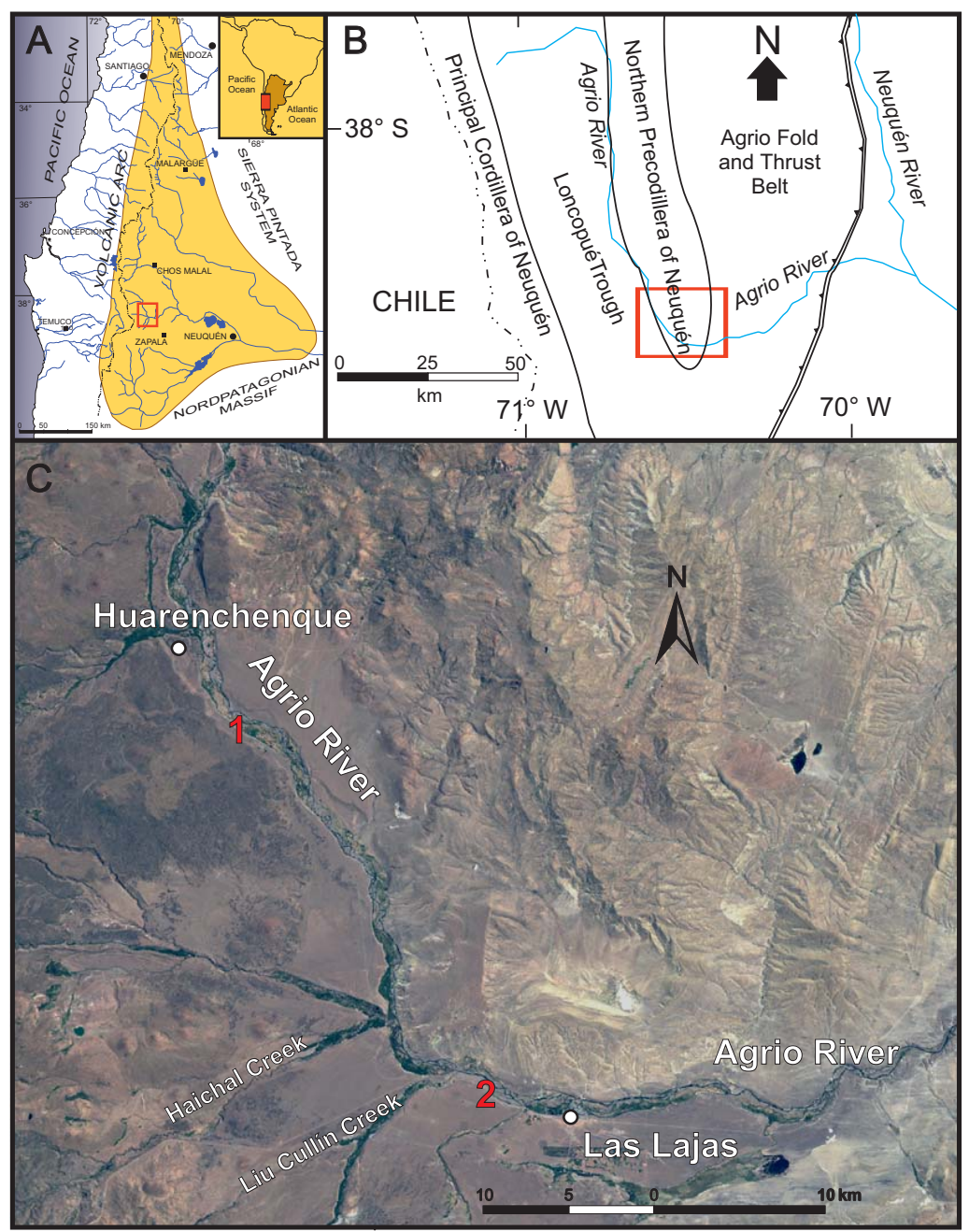

FIG. 1. A. Location of the study area in the Neuquén Basin. B. Sketch of the main structural units of the region (Principal Cordillera of Neuquén, Northern Precordillera of Neuquén and Loncopué Trough), and location of the study area along the Agrio River. C. Satellite image of the Huarenchenque place and the Agrio River. The study areas are outlined with red boxes.

Huarenchenque Formation. Specific objectives are (i) to present the results of the sedimentary facies analysis and the bidimensional architecture of the deposits, (ii) to delineate the main patterns of clastic and pyroclastic deposition, (iii) to investigate the distribution and proportion of syneruptive and intereruptive products and processes, and (iv) to evaluate in what extent coeval explosive volcanism impacts on fluvial sedimentation.

\section{Geological setting and general features}

The site under study (Fig. 1) is located in the province of Neuquén (near the Argentine-Chilean border) in an area known as Alto del Copahue-Pino Hachado. Geologically, it straddles the border between the Loncopue trough (Ramos, 1978) and the Northern Precordillera of Neuquén (Ramos et al., 2011). The Loncopué trough is a Plio-Quaternary basin mainly filled with large effusive basaltic flows from monogenetic volcanic vents. The subsurface morphology is constituted by different depocenters consisting of thick Mesozoic successions (Ramos et al., 2011). The Northern Precordillera of Neuquén, which was produced by a tectonic inversion of Triassic-Jurassic halfgrabens, displays thick Jurassic and Cretaceous deposits crossed by Cretaceous to Palaeogene volcanic and subvolcanic intrusive bodies (Ramos et al., 2011). 
The Huarenchenque Formation is a volcano sedimentary unit composed of polymictic conglomerates with the predominance of basaltdominated clasts, coarse-medium-grained conglomeratic sandstones and medium- to coarsegrained sandstones in lenticular or tabular lithosomes, displaying profuse cross bedding. Ignimbrite deposits as well as primary and reworked tuff levels are present locally. This unit was firstly described in the western sector of the Neuquén Province (Argentina) by Zanettini (1979). Its main outcrops are located along the western and southern banks of the Agrio River between latitude $38^{\circ}$ and $38^{\circ} 30^{\prime} \mathrm{S}$ and longitude $70^{\circ} 20^{\prime}$ and $70^{\circ} 30^{\prime} \mathrm{W}$. It also crops out in the westernmost area of Haichal and Liu Cullín creeks towards the Pino Hachado region (Fig. 1). According to Leanza et al. (2001) the Huarenchenque Formation was accumulated along the Pleistocene; it overlies Pleistocene basaltic lavas (Zanettini, 1979) dated at $1.44 \pm 0.08 \mathrm{Ma}$ (Kay et al., 2006) and $1.31 \pm 0.07 \mathrm{Ma}$ (Galland et al., 2007); therefore, these data provide a maximum age for the accumulation of the studied deposits.
Figure 2 shows the Neogene-Quaternary stratigraphy of the Neuquén Andes between $38^{\circ} \mathrm{SL}$ and $39^{\circ} \mathrm{SL}$ (compiled from García Morabito and Folguera, 2005), and the Huarenchenque Formation lies with and indefinite contact on volcanic rocks of the Cola de Zorro Formation and the Romero Basalt. The most complete characterization of the Haurenchenque Formation was made by Stura and Mazzoni (1994). These authors described to main facies associations, one dominated by coarse-grained fluvial deposits and the other characterized by pyroclastic deposits. According to Stura and Mazzoni (1994) and García Morabito and Folguera (2005), the Huarenchenque Formation developed in a braided fluvial environment that was affected by coeval volcanic activity.

\section{Methods}

Along the study area (Fig. 1), four sections were described in detail. The dataset was acquired by bed logging and line drawing of lithofacies architecture in the field and on panoramic photomosaics of outcrop exposures. At each site, detailed stratigraphic logs were

\begin{tabular}{|c|c|c|c|}
\hline HOLOCENE & \multicolumn{3}{|c|}{ ARC AND BACKARC LAVAS, FOOTHILL AND FLUVIAL SEDIMENTS } \\
\hline \multirow{3}{*}{ PLEISTOCENE } & \multirow{3}{*}{$\begin{array}{l}\text { PLIOCENE-PLEISTOCENE } \\
\text { STRATOVOLCANOES } \\
\text { (basalts, andesites, } \\
\text { trachiandesites, } \\
\text { volcanic agglomerates, tuffs) }\end{array}$} & $\begin{array}{l}\text { AVESTRUZ } \\
\text { FORMATION } \\
\text { (olivine basalts) }\end{array}$ & $\begin{array}{c}\text { HUARENCHENQUE FORMATION } \\
\text { (conglomerates, sandstones, } \\
\text { ignimbrites, tuffs) }\end{array}$ \\
\hline & & & \\
\hline & & $\begin{array}{l}\text { ROMERO } \\
\text { FORMATION } \\
\text { (olivine basalts) }\end{array}$ & $\begin{array}{l}\text { CODIHUE FORMATION } \\
\text { (conglomerates) }\end{array}$ \\
\hline PLIOCENE & \multicolumn{3}{|c|}{$\begin{array}{c}\text { COLA DE ZORRO FORMATION } \\
\text { (volcanic agglomerates, conglomerates, andesites, basalts) }\end{array}$} \\
\hline \multirow{2}{*}{ MIOCENE } & \multicolumn{3}{|c|}{$\begin{array}{c}\text { MITRAUQUÉN FORMATION } \\
\text { (ignimbrites, andesite lavas, conglomerates) }\end{array}$} \\
\hline & \multicolumn{3}{|c|}{$\begin{array}{c}\text { CURA MALLÍN FORMATION } \\
\text { (ignimbrites, tuffs, volcanic breccias, andesites, basalts) }\end{array}$} \\
\hline
\end{tabular}

FIG. 2. Neogene stratigraphy of the Neuquén Andes between $38^{\circ}$ and $39^{\circ} \mathrm{S}$ (compiled from García Morabito and Folguera, 2005). 
measured and cross- sections depicting the distribution of lithofaces were constructed over a distance of 100 to $300 \mathrm{~m}$. The goal of bidimensional architectural analysis was to describe the geometry of lithological units, discriminate their lower and upper boundaries, the internal lithological subdivisions and discontinuity surfaces as well as their lateral and vertical facies changes.

\section{Facies analysis}

We have described and classified twelve sedimentary lithofacies types in the Huarenchenque Formation (Table 1). The lithofacies classification used in this study follows the system introduced by Miall (1977, 1978) and Rust (1978), and subsequently expanded by several authors for fluvial and alluvial-related deposits in volcanic settings (Smith, 1986, 1987; Waresback and Turbeville, 1990; Zanchetta et al., 2004). Three new codes have been introduced for describing primary pyroclastic deposits (Table 1). In order to define depositional settings, lithofacies are grouped into two facies associations: fluvial and pyroclastic (Table 1).

\subsection{Fluvial facies association}

\subsubsection{Description}

Two facies types composed of volcaniclastic pebbly and sandy deposits are intimately associated in the fluvial facies association (Table 1). Typically, the conglomerates are moderately sorted and clastsupported. The clasts are subangular to rounded, and their size varies between granule and cobble with a dominance of medium to coarse pebbles. Outsized clasts (up to $50 \mathrm{~cm}$ ) are common in some beds. The matrix can be described as moderately sorted with a range of grain size from fine- to coarse-grained volcaniclastic sand. Pebble composition is dominated by country rocks (basalt, andesite, rhyolite and granite clasts, Fig. 3A), accompanied by well rounded pumice fragments supplied by coeval volcanic eruptions, and less common muddy intraclasts derived from the reworking of the fluvial flood plain and/or bar tops.

Conglomerate beds occur as stacked or single bodies and display both sheet and channelized geometries. Bottom contacts usually show signs of erosion. These deposits contain a range of internal sedimentary structures, such as planar (Gh) and low angle (Gl) stratification and cross-bedding (Gt, Gp). In this area cross-bedded conglomerates occur as laterally continuous medium-scale deposits (Gt) and as the infill of isolated scours or pools (Gp); these deposits are characterised by large-scale planar foresets, by a progressive lowering in the dip of foresets in accretion direction and by a marked concave upwards basal surface (Fig. 3B). Internally, some conglomerate beds display normal grading. Larger clasts $(>10$ $\mathrm{cm})$ are usually imbricated with their longest axis perpendicular to the flow direction; however, in some instances, the absence of elongated clasts prevents a reliable assessment of clast imbrication. In places, elongate clasts are oriented subhorizontally.

Some conglomerate beds consist of moderately to poorly sorted, massive or crudely bedded, poorly imbricated, clast-supported gravels with an abundant matrix rich in coarse sand and granules (Lithofacies $\mathrm{Gm})$; these deposits are 0.3 to $0.5 \mathrm{~m}$ thick and are very variable in terms of geometry, ranging from laterally continuous beds to single scour fills.

Massive, matrix supported and poorly sorted conglomerates essentially composed of volcanic rock fragments are less common ( $\mathrm{Gms}$ facies). These deposits occur as thick (more than $1.5 \mathrm{~m}$ ) single bodies towards the southern sector of the study area and display both sheet and lobe (convex up top) geometries.

Sandstones and gravelly sandstones of the Huarenchenque Formation show a continuum range based on gravel content. The lithofacies types are characterised by different modes of stratification (parallel laminations, low-angle and high-angle cross-stratification, Table 1). Bed thickness varies between 0.10 and $1.50 \mathrm{~m}$, but on average the beds are around $0.50 \mathrm{~m}$.

Commonly, these beds are laterally continuous layers, whereas scour and fill structures are uncommon. The sand population is moderately sorted and is composed of subrounded to rounded basaltic and/or pumice grains (Fig. 4A). The pebbles of the gravelly sandstones as well as those of thin gravel lineations are essentially rounded basaltic rock fragments. The composition of sandstone beds is not uniform. Some beds are composed of basaltic grains (blue sandstones) while others are rich in pumice clasts. It is also common an alternation of basaltic-rich and pumice-rich laminae in the foresets of cross-bedded sandstones (Fig. 4B).

\subsubsection{Interpretation}

Fluvial lithofacies are characteristic of stream flow deposits. They are interpreted as the result of rapid accumulation under fast-moving, heavily sediment-laden turbulent flows in a gravelly braided 
TABLE 1. DESCRIPTION AND INTERPRETATION OF THE LITHOFACIES DEFINED IN THIS PAPER. (*)

\begin{tabular}{|c|c|c|c|c|c|}
\hline $\begin{array}{l}\text { Facies } \\
\text { code }\end{array}$ & Texture, composition & Primary structures & $\begin{array}{l}\text { Complementary } \\
\text { features }\end{array}$ & Interpretation & $\begin{array}{c}\text { Facies } \\
\text { association }\end{array}$ \\
\hline Gh & $\begin{array}{l}\text { Volcaniclastic } \\
\text { (basalt-dominated) } \\
\text { conglomerate. }\end{array}$ & $\begin{array}{l}\text { Plane-bedding. } \\
\text { Crude fining upwards } \\
\text { arrangement. Important } \\
\text { lateral continuity of } \\
\text { lithosomes. }\end{array}$ & - & $\begin{array}{l}\text { High-energy } \\
\text { supercritical flash } \\
\text { flows. }\end{array}$ & \multirow{10}{*}{ FLUVIAL } \\
\hline Gl & $\begin{array}{l}\text { Volcaniclastic } \\
\text { (basalt-dominated) } \\
\text { conglomerate. }\end{array}$ & $\begin{array}{l}\text { Low-angle cross-bedding. } \\
\text { Important lateral continuity } \\
\text { of lithosomes. }\end{array}$ & - & $\begin{array}{l}\text { High-energy } \\
\text { supercritical flash } \\
\text { flows. }\end{array}$ & \\
\hline Gt & $\begin{array}{l}\text { Volcaniclastic } \\
\text { (basalt-dominated) } \\
\text { conglomerate. }\end{array}$ & $\begin{array}{l}\text { Medium- and high-angle } \\
\text { cross-bedding. Crude fining } \\
\text { upwards arrangement. } \\
\text { Important lateral continuity. } \\
\text { Erosional lower surface. } \\
\text { Main palaeocurrent trends } \\
\text { to the south. }\end{array}$ & - & $\begin{array}{l}\text { Downstream } \\
\text { migration and } \\
\text { accretion of braid } \\
\text { bars. }\end{array}$ & \\
\hline Gp & $\begin{array}{l}\text { Volcaniclastic } \\
\text { (basalt-dominated) } \\
\text { conglomerate. }\end{array}$ & $\begin{array}{l}\text { Large-scale, medium- and } \\
\text { high-angle cross-bedding. } \\
\text { Lenticular lithosomes and } \\
\text { marked erosional lower } \\
\text { surface. Main palaeocurrent } \\
\text { trends to the south. }\end{array}$ & - & $\begin{array}{l}\text { Infill of isolated } \\
\text { pools by lateral } \\
\text { and/or oblique bar } \\
\text { progradation. }\end{array}$ & \\
\hline Gt(rev) & $\begin{array}{l}\text { Volcaniclastic } \\
\text { (basalt-dominated) } \\
\text { conglomerate. }\end{array}$ & $\begin{array}{l}\text { Medium-angle cross- } \\
\text { bedding oriented to the } \\
\text { north. Sets with discrete } \\
\text { lateral continuity. }\end{array}$ & - & $\begin{array}{l}\text { High energy } \\
\text { supercritical flash } \\
\text { flows. Cross-stratified } \\
\text { backsets of antidune } \\
\text { bedforms. }\end{array}$ & \\
\hline $\mathrm{Gm}$ & $\begin{array}{l}\text { Volcaniclastic } \\
\text { (basalt-dominated) } \\
\text { conglomerate. }\end{array}$ & $\begin{array}{l}\text { Massive.Poorly imbricated } \\
\text { clasts.Laterally continuous } \\
\text { beds and single scour fills. }\end{array}$ & - & $\begin{array}{l}\text { Deposits of } \\
\text { hyperconcentrated } \\
\text { flood flows }\end{array}$ & \\
\hline Gms & $\begin{array}{l}\text { Volcaniclastic } \\
\text { (basalt-dominated) } \\
\text { conglomerate. Matrix } \\
\text { supported. Poorly sorted. }\end{array}$ & - & $\begin{array}{l}\text { Sheet-like and lobate } \\
\text { geometries. }\end{array}$ & $\begin{array}{l}\text { High-density debris } \\
\text { flows. }\end{array}$ & \\
\hline GSh & $\begin{array}{l}\text { Volcaniclastic (basalt- } \\
\text { and basalt/pumice- } \\
\text { dominated) gravelly } \\
\text { sandstone. }\end{array}$ & $\begin{array}{l}\text { Plane-bedding. Important } \\
\text { lateral continuity of } \\
\text { lithosomes. }\end{array}$ & $\begin{array}{l}\text { May include imbricated } \\
\text { basaltic phenoclasts } \\
\text { locally. }\end{array}$ & $\begin{array}{l}\text { High-energy } \\
\text { supercritical flash } \\
\text { flows. }\end{array}$ & \\
\hline GSl & $\begin{array}{l}\text { Volcaniclastic (basalt- } \\
\text { and basalt/pumice- } \\
\text { dominated) gravelly } \\
\text { sandstone. }\end{array}$ & $\begin{array}{l}\text { Low-angle cross-bedding. } \\
\text { Important lateral continuity } \\
\text { of lithosomes. }\end{array}$ & $\begin{array}{l}\text { May include imbricated } \\
\text { basaltic phenoclasts } \\
\text { locally. }\end{array}$ & $\begin{array}{l}\text { High-energy } \\
\text { supercritical flash } \\
\text { flows. }\end{array}$ & \\
\hline GSt & $\begin{array}{l}\text { Volcaniclastic (basalt- } \\
\text { and pumice-dominated) } \\
\text { gravelly sandstone. }\end{array}$ & $\begin{array}{l}\text { Trough cross-bedding. } \\
\text { Main palaeocurrent trends } \\
\text { to the south. Lateral } \\
\text { continuity of lithosomes. }\end{array}$ & $\begin{array}{l}\text { May include imbricated } \\
\text { basaltic phenoclasts } \\
\text { locally. Foresets could } \\
\text { be entirely composed } \\
\text { of basaltic grains (blue } \\
\text { sandstones) or pumice } \\
\text { grains. Other foresets } \\
\text { consist of alternating } \\
\text { basaltic- and pumice- } \\
\text { rich laminae. }\end{array}$ & $\begin{array}{l}\text { Downstream accretion } \\
\text { of } 3 \mathrm{D} \text { dunes or } \\
\text { sandwaves. }\end{array}$ & \\
\hline
\end{tabular}


table 1 continued.

\begin{tabular}{|c|c|c|c|c|c|}
\hline $\begin{array}{l}\text { Facies } \\
\text { code }\end{array}$ & Texture, composition & Primary structures & $\begin{array}{l}\text { Complementary } \\
\text { features }\end{array}$ & Interpretation & $\begin{array}{c}\text { Facies } \\
\text { association }\end{array}$ \\
\hline Shl & $\begin{array}{l}\text { Volcaniclastic (basalt- } \\
\text { and pumice-dominated) } \\
\text { sandstone. }\end{array}$ & $\begin{array}{l}\text { Plane-bedding. Important } \\
\text { lateral continuity of } \\
\text { lithosomes. }\end{array}$ & $\begin{array}{l}\text { May include imbricated } \\
\text { basaltic phenoclasts } \\
\text { locally. }\end{array}$ & $\begin{array}{l}\text { High-energy and/ } \\
\text { or very shallow } \\
\text { unchanellised flows. } \\
\text { Probably bar top } \\
\text { deposits. }\end{array}$ & \multirow{4}{*}{ FLUVIAL } \\
\hline S1 & $\begin{array}{l}\text { Volcaniclastic (basalt- } \\
\text { and pumice-dominated) } \\
\text { sandstone. }\end{array}$ & $\begin{array}{l}\text { Low-angle cross- } \\
\text { bedding. Important lateral } \\
\text { continuity of lithosomes. }\end{array}$ & $\begin{array}{l}\text { May include imbricated } \\
\text { basaltic phenoclasts } \\
\text { locally. }\end{array}$ & $\begin{array}{l}\text { High-energy and/ } \\
\text { or very shallow } \\
\text { unchanellised flows. } \\
\text { Probably bar top } \\
\text { deposits. }\end{array}$ & \\
\hline St & $\begin{array}{l}\text { Volcaniclastic (basalt- } \\
\text { and pumice-dominated) } \\
\text { sandstone. }\end{array}$ & $\begin{array}{l}\text { Trough cross-bedding. } \\
\text { Main palaeocurrent trends } \\
\text { to the south. Lateral } \\
\text { continuity of lithosomes. }\end{array}$ & $\begin{array}{l}\text { May include imbricated } \\
\text { basaltic phenoclasts } \\
\text { locally. Foresets could } \\
\text { be entirely composed } \\
\text { of basaltic grains (blue } \\
\text { sandstones) or pumice } \\
\text { grains. Other foresets } \\
\text { consist of alternating } \\
\text { basaltic- and pumice- } \\
\text { rich laminae. }\end{array}$ & $\begin{array}{l}\text { Downstream } \\
\text { accretion of 3D } \\
\text { dunes or sandwaves. }\end{array}$ & \\
\hline $\begin{array}{l}\text { Gh-Gl/ } \\
\text { Sh-Sl }\end{array}$ & $\begin{array}{l}\text { Heterolithic } \\
\text { volcaniclastic } \\
\text { (basalt-dominated) } \\
\text { conglomerate, gravelly } \\
\text { sandstone and/or } \\
\text { sandstone. }\end{array}$ & $\begin{array}{l}\text { Fining upwards units. } \\
\text { Low-angle bedding and } \\
\text { parallel laminations (plane } \\
\text { beds). }\end{array}$ & - & $\begin{array}{l}\text { High-energy and/ } \\
\text { or very shallow } \\
\text { unchanellised flows. } \\
\text { Probably bar top } \\
\text { deposits. Alternating } \\
\text { waxing and waning } \\
\text { conditions in the } \\
\text { flow. }\end{array}$ & \\
\hline $\mathrm{LT}(1)$ & $\begin{array}{l}\text { Lapilli tuff and ash } \\
\text { tuff, well sorted. }\end{array}$ & $\begin{array}{l}\text { Massive or faint parallel } \\
\text { lamination. Mantle } \\
\text { bedding. }\end{array}$ & $\begin{array}{l}\text { Rare accidental basaltic } \\
\text { clasts. }\end{array}$ & $\begin{array}{l}\text { Pyroclastic fall } \\
\text { deposits. }\end{array}$ & \multirow[b]{3}{*}{ PYROCLASTIC } \\
\hline $\mathrm{LT}(2)$ & $\begin{array}{l}\text { Lapilli tuff. Pumice } \\
\text { lapilli in an ash matrix. }\end{array}$ & $\begin{array}{l}\text { Massive. Crude } \\
\text { lamination. Sectors } \\
\text { inversely graded. }\end{array}$ & $\begin{array}{l}\text { Isolated basaltic blocks. } \\
\text { Pockets and linea- } \\
\text { tions of medium- } \\
\text { grained volcaniclas- } \\
\text { tic gravels. }\end{array}$ & $\begin{array}{l}\text { Deposition from } \\
\text { turbulent pyroclastic } \\
\text { density currents. }\end{array}$ & \\
\hline LT(3) & $\begin{array}{l}\text { Alternation of ash tuffs } \\
\text { and lapilli tuffs. }\end{array}$ & $\begin{array}{l}\text { Marked lamination } \\
\text { composed of couplets } \\
\text { of lapilli- and ash-tuff. } \\
\text { Laterally continuous } \\
\text { lithosomes. Faint cross- } \\
\text { bedding towards the base } \\
\text { of the lithosome. }\end{array}$ & - & $\begin{array}{l}\text { Deposition from } \\
\text { pyroclastic surges. }\end{array}$ & \\
\hline
\end{tabular}

(*) Facies codes according to Miall $(1977,1978)$ and Rust (1978), and subsequently expanded by Smith (1986, 1987), Waresback and Turbeville (1990) and Zanchetta et al. (2004).

stream with laterally unstable channels, as suggested by the scoured basal contacts, imbricated clasts, clast-supported texture, and the lack of intervening fine-grained deposits (Miall, 1977, 1978; Rust, 1978). Conglomerates, gravelly sandstones and sandstones are considered to be bedload deposits. Horizontally laminated and low-angle inclined beds as well as reverse-oriented cross-stratified sets indicate high energy supercritical flash flows. Trough and laterally continuous bedsets of conglomerates probably 

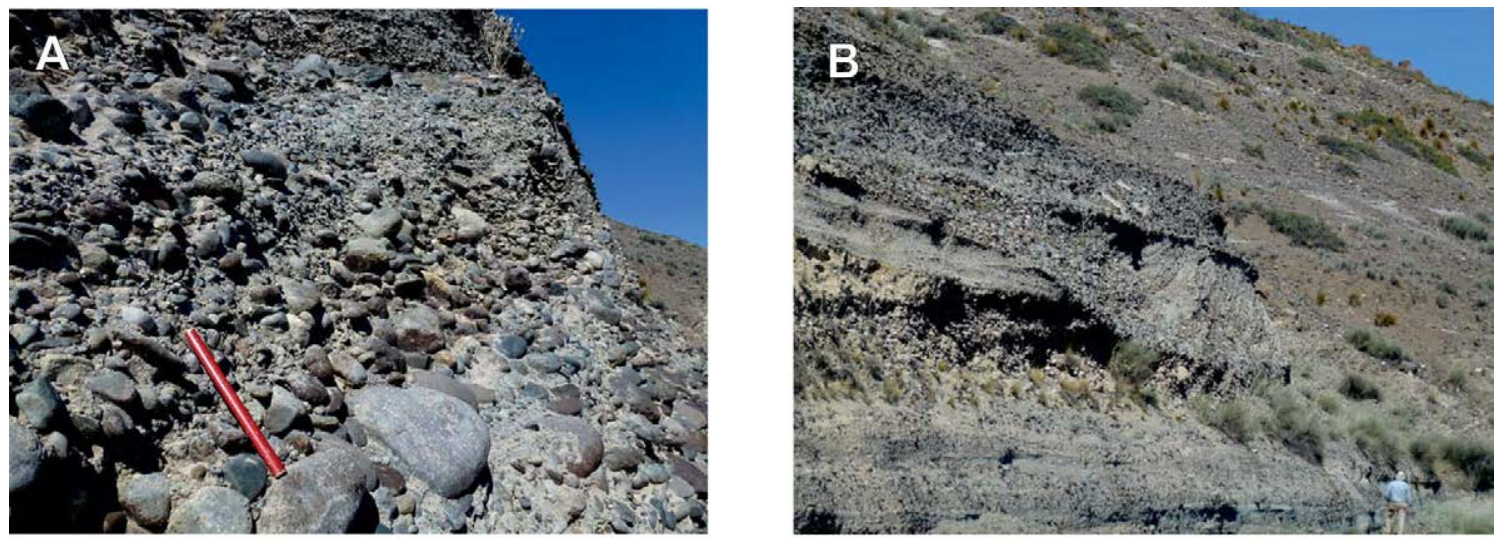

FIG. 3. Fluvial facies association (location 2 in Fig. 1). A. Clast-supported and moderately sorted volcaniclastic conglomerate composed of rounded pebbles and cobbles. The red pencil is $30 \mathrm{~cm}$ long. B. Isolated scour pool with a marked concave upwards basal surface filled with a clast-supported conglomerate deposit (person for scale).
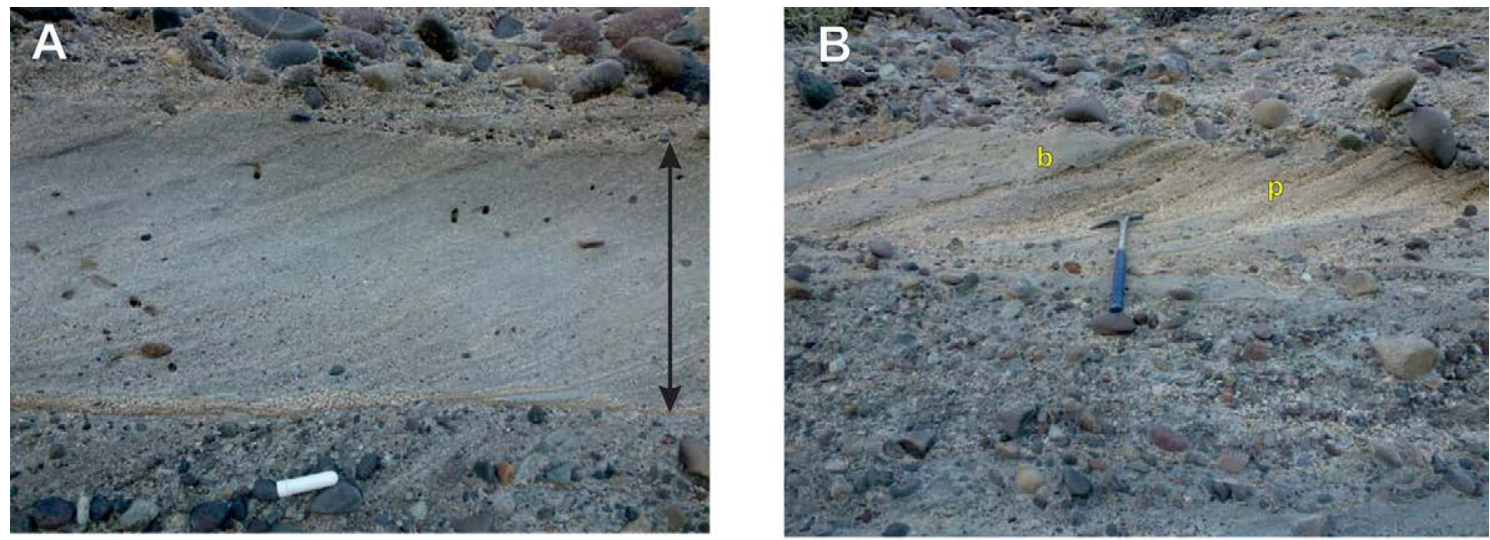

FIG. 4. Fluvial facies association (location 2 in Fig. 1). A. Close view of a cross-stratified set (double arrow) characterized by tangential foresets composed of gravelly sandstones and coarse-grained sandstones. This deposit is associated with cross-stratified and imbricated conglomerate beds (the white pen cover is $7 \mathrm{~cm}$ long). B. Cross-stratified bed with alternating basalt-dominated (b) and pumice-dominated (p) tangential foresets (hammer is $30 \mathrm{~cm}$ long).

represent frontal accretion of longitudinal bars and/ or the migration of 3D gravel dunes (Allen, 1982; Lang et al., 2012). In turn, sandstone trough crossbedded sets would have been deposited by waning flows as the result of downstream migration of 3D dunes developed on bar tops and margins, or in secondary channels of the braided fluvial system. Gp cross-bedded lenticular conglomerate lithosomes with a conspicuous downstream decrease in the dip of foresets are interpreted as the infill of isolated pools by bar progradation (Khadkikar, 1999). The crudely stratificated conglomerates $(\mathrm{Gm})$ are interpreted to have been deposited by rapid suspension fallout with some traction on the bed by turbulent hyperconcentrated flood flows (Smith, 1986; Sohn et al., 1999). On the other hand, lithofacies Gms is assigned to high density debris flows, based on poorly sorting, matrix-supported texture and lack of primary sedimentary structures (Miall, 1978, 1985).

\subsection{Pyroclastic facies association}

\subsubsection{Description}

Pyroclastic deposits are characterized by a whitish to pale pink colour. They essentially consist of lapilli tuff beds in a vitric ash matrix. 
Lithofacies LT(1) mainly consists of well sorted angular to subrounded pumice lapilli and vitric ash (Table 1). The deposits are massive (sometimes with faint lamination) and range in thickness from $0.10 \mathrm{~m}$ to $0.40 \mathrm{~m}$, and are commonly intercalated in the volcaniclastic-rich fluvial succession.

Lithofacies LT(2) is composed of subangular to subrounded, matrix to clast supported, pumice lapilli with scarce basaltic blocks in a vitric ash matrix. (Table 1, Fig. 5A) The main deposit of this lithofacies is $400 \mathrm{~m}$ long with a thickness of about $10 \mathrm{~m}$ and overall unwelded. Its basal section is composed of a dark grey, massive, very poorly sorted volcaniclastic pebbly sandstone including upsized and very angular basaltic boulders incorporated from the cliffs and screes bounding the palaeo-valley where the flow was channelized (LT(2)a in Figs. 5B, C). The middle section consists of a light coloured massive pumice lapilli with isolated angular volcanic blocks; towards the base it includes "pockets" and "lineations" of subrounded and rounded basaltic pebbles incorporated into the flow from previously deposited fluvial gravels (LT(2)b in Fig. 5D). The lower surface of this unit is sharp and irregular due to scour and loading (Figs. 5C, D). The upper section lies on a marked non-erosional surface and is composed of a pink pumice lapilli with crude lamination and showing a reverse grading
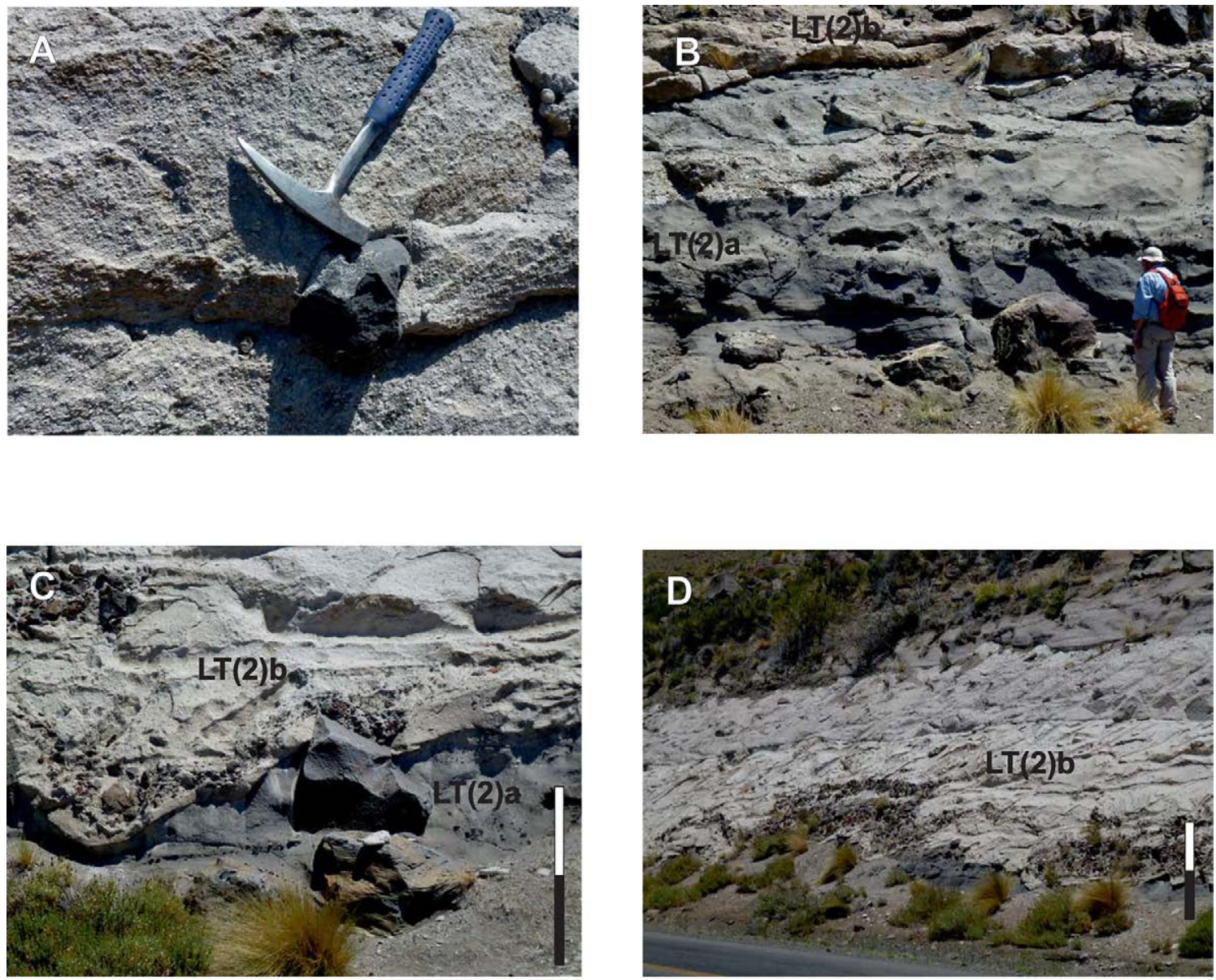

FIG. 5. Pyroclastic facies association (location 1 in Fig. 1). A. Lithofacies LT(2): pumice lapilli including an upsized basaltic block. B. Dark grey, massive, very poorly sorted volcaniclastic pebbly sandstone (LT2(a)) including upsized and very angular basaltic boulders. C. and D. Close and general views of light coloured massive pumice lapilli (LT2(b)) with isolated angular volcanic blocks. The lower surface of this unit is sharp and irregular due to scour and loading. Towards the base, note the concentration of basaltic pebbles incorporated into the flow from previously deposited fluvial gravels (LT2(a)). Reference bars are $1 \mathrm{~m}$ long. 
of pumice fragments from its middle part up to the top (LT(2)c in Fig. 6), where the facies is suddenly replaced by fluvial deposits.

Lithofacies LT(3) consists of single 0.8 to $1 \mathrm{~m}$ thick lithosome characterised by a bipartite alternation of light grey ash tuffs and lapilli tuffs almost entirely composed of juvenile components (Table 1, Fig. 7A). The deposits are parallel-laminated and laterally continuous. Individual laminae are on the order of millimeters to a few centimetres. Towards its basal part, this unit shows a faded cross-bedding development (Fig. 7B).

\subsubsection{Interpretation}

The good sorting and stratification of the LT(1) lithofacies indicated that it represents air fall pyroclastic deposits (Teruggi et al., 1978; Mathisen and Vondra, 1983; Mazzoni, 1986) . However, mantle bedding, considered a diagnostic character of these deposits (Sparks and Walker, 1973; Teruggi et al., 1978) was not observed due to limited extension of outcrops and beds.

The deposits of lithofacies LT(2) are interpreted to have been deposited rapidly from pyroclastic density currents without tractional grain segregation (Branney and Kokelaar, 2002). Variable grading patterns of lapilli clasts are interpreted to indicate progressive aggradation from turbulent pyroclastic density currents in association with either waxing or waning of volcanic eruptions (Sohn et al., 2013).

The pyroclastic couplets of lithofacies LT(3) are interpreted as the result of the passage of single density stratified surges, such as those recorded in modern eruptions (Fisher, 1990; Edmonds and Heard, 2005; Vázquez and Ort, 2006). In such a context, the ash and lapilli tuff cross-stratified set represents the downstream migration of surge-induced "progressive" sand waves or dunes (cf. Cole, 1991; Schmincke et al., 1973; Gençalioğlu-Kuşcu et al., 2007).

\section{Architecture of the fluvial deposits}

Based on the geometry and orientation of crossbeds, most of the exposures of the Huarenchenque Formation roughly coincide with palaeo-flow directions. The architectural analysis of these

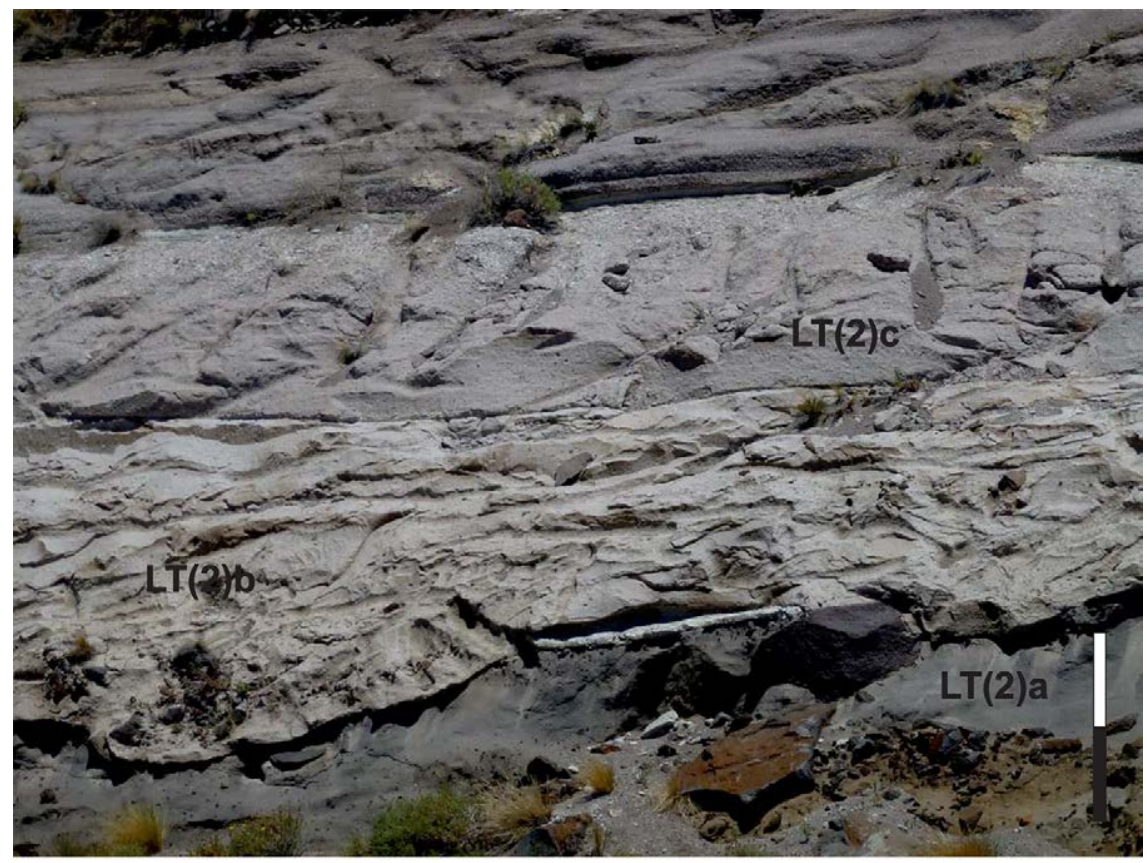

FIG. 6. Pyroclastic facies association (location 1 in Fig. 1). Deposit of a pyroclastic density current composed of three clearly defined units: LT2(a) massive and very poorly sorted volcaniclastic pebbly sandstone including upsized and angular basaltic boulders; LT2(b) light coloured massive pumice lapilli showing pockets of subrounded and rounded basaltic pebbles; LT2(c) crudely laminated pumice lapilli with clearly developed reverse grading of pumice fragments towards the top. Reference bar is $1 \mathrm{~m}$ long. 

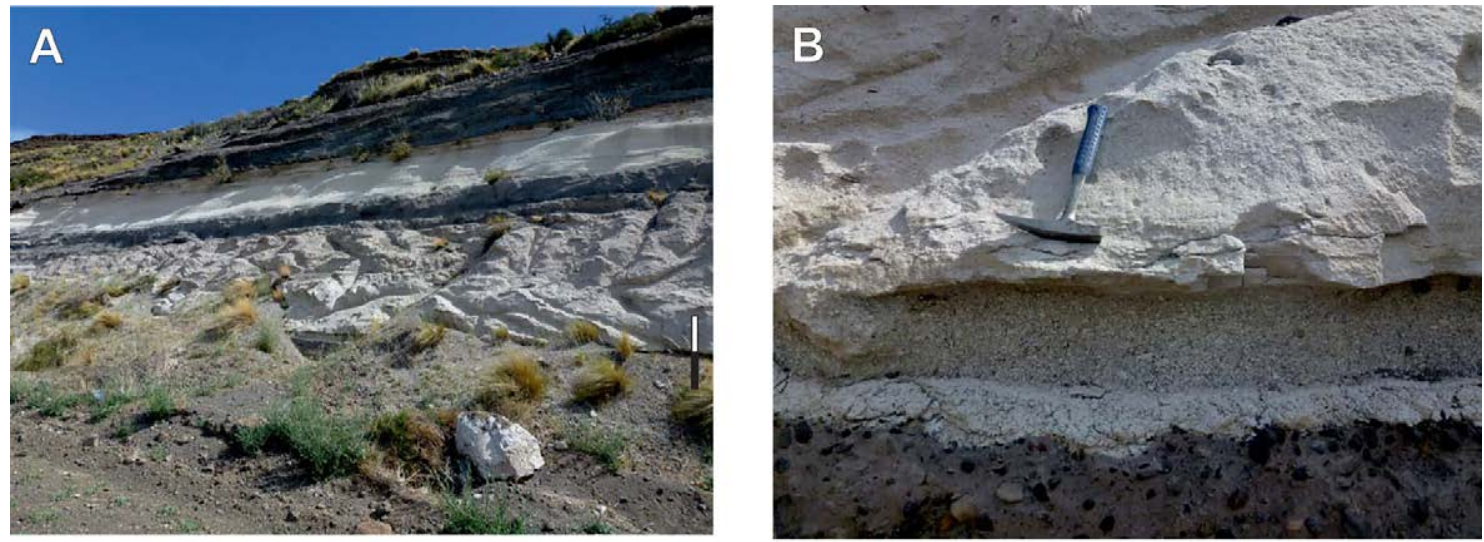

FIG. 7. Pyroclastic facies association (location 1 in Fig. 1). A. General view of two different pyroclastic lithofacies. The unit located at the base of the cliff is composed of vitric light grey ash tuffs and lapilli tuffs assigned to lithofacies LT(3) and interpreted as a single density stratified surge deposit. The upper unit intercalated between two dark deposits of the fluvial facies association consists of well sorted pumice lapilli and coarse vitric ash assigned to lithofacies LT(1) and interpreted as a typical air fall pyroclastic deposit (reference bar is $1 \mathrm{~m}$ long). B. Close up of lithofacies LT(3) with a lapilli tuff at the base and a faint-laminated ash tuff on top (the hammer is $30 \mathrm{~cm}$ long).

deposits shows that it is quite difficult to define fluvial strata-sets of larger hierarchy (the so-called channel belt deposits of Bridge and Lunt, 2005). Several stratigraphic surfaces have been traced; however it is also difficult to rank their respective hierarchy (cf. Ielpi et al., 2014).

As shown in figures 8, 9, 10 and 11 the deposits of the Huarenchenque Formation are characterized by i. common laterally continuous beds of conglomerates and subordinated sandstones, ii. high proportion of massive, crudely bedded and imbricate conglomerates, associated with plane bedded and/or low-angle conglomerate layers, and iii. very discrete amalgamation of cross-bedded conglomerates, gravelly sandstones and sandstones. These features depart from the classical model for gravelly braided rivers (Lunt et al., 2004; Bridge and Lunt, 2005), since they are dominated by median-scale cross-bedded deposits, associated with planar and small-scale cross-strata.

Laterally extensive beds of facies Gm, Gh-Gl, Gt, GSh-GSl (Figs. 8, 9) are the result of coarsegrained high bed-load flows, and represent the deposits of longitudinal bars and stream floods within rapidly evolving shallow braided channels. Only in a few cases the cross-bedded sandstones and conglomerates are grouped to form cosets that can be interpreted as deposits of unit bars
(Fig. 8) (Bridge and Lunt, 2005; Sambrook Smith et al., 2006). More commonly the cross-bedded sets are solitary and show a progressive thickness increase downstream, having the bed marked wedge geometry (Fig. 9). These deposits are the result of the migration of subcritical sand dunes along secondary channels and/or on the bar top of the braided system. The cross-stratified conglomerates appear as the infill of lens-shaped solitary lithosomes with a high-relief concave upwards basal surface (Figs. 10, 11). They are formed by large-scale planar foresets showing a marked decrease in dip in the accretion direction (Fig. 11). These deposits are interpreted as the rapid lateral and/or oblique accretion of cross-bars into deep and narrow channels.

The deposits of the Huarenchenque Formation, dominated by laterally extensive coarse-grained facies (Figs. 8, 9) resemble those of sandur plains, since individual channels are often shallow during "normal" flow conditions (Maizels, 1993; Stokes et al., 2012) and prone to sheet flooding during periods of high discharge. The isolated crossbedded conglomerates with large-scale foresets were deposited within deeper channels during sustained high-magnitude flow conditions. Flows of this magnitude commonly occur in periglacial fluvial systems during periods of abnormally high discharge (Stokes et al., 2012). 


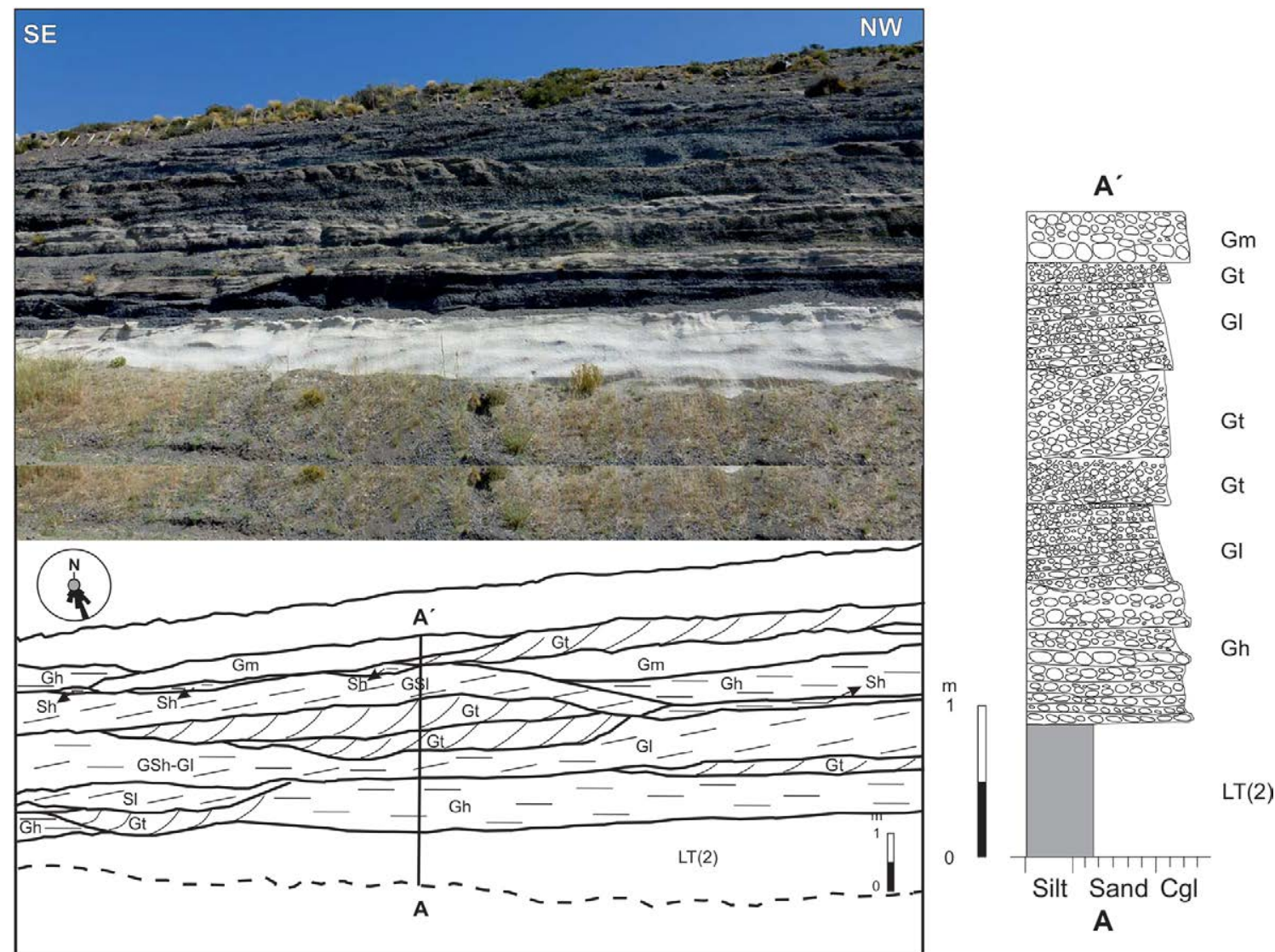

FIG. 8. Photomosaic, bedding architecture, facies organization and palaeocurrents (measured on the foreset dip direction) of the cliff face at the southern sector of location 1 (see Fig. 1). Facies code in table 1.

\section{Discussion}

\subsection{Palaeogeography, relationship to volcanic activity and controls on fluvial system development}

In the study area, the Huarenchenque Formation is the result of sedimentary accumulation in the palaeo-Agrio river valley and its (paleo) tributaries, which drained the eastern slopes of the Andean Cordillera. The main paleo-valley is located at the place where the Agrio river is running today. Thus, the studied exposures along the western and southern sides of the Agrio valley are the result of the fluvial incision of older (Huarenchenque) deposits. These characteristics suggest that the fluvial Agrio system was active at roughly the same location at least since de Upper Pleistocene.
In the Huarenchenque Formation the two facies associations defined in the present study show a clear physical separation (Figs. 7A and 8). Thus, the sedimentation occurred in two distinct phases: one short-lived syneruptive phase (represented at least by two pyroclastic intercalations) and another longlived intereruptive phase (Smith 1987, 1991). These fluctuations occur at a much higher frequency than tectonically or climatically induced modifications (Smith, 1991; Khalaf, 2012).

During syneruptive phases, the paleo-Agrio river valley was almost entirely occupied by deposits related to explosive volcanism, in particular those due to pyroclastic flows (facies LT(2) and LT(3)). Though precise ages of these deposits are still lacking, according to geomorphological relationships it is assumed that these episodes were generated by the Andean arc volcanism of the Southern Volcanic Zone (Stern, 


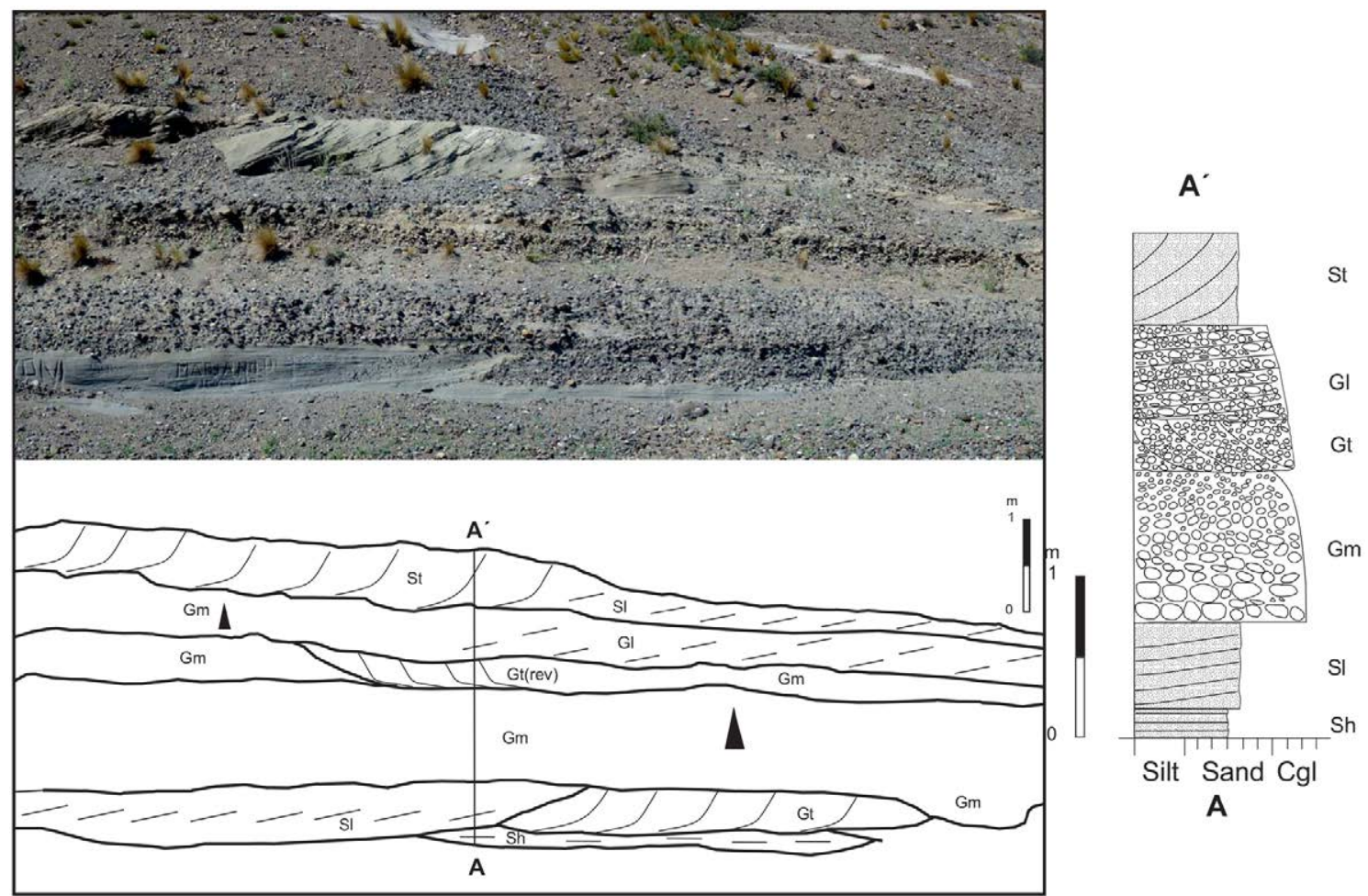

FIG. 9. Example of bedding architecture and facies organization in the fluvial facies association, traced from a photo mosaic at the western sector of location 2 (see Fig. 1). Facies code in table 1.

2004) and especially during high-explosive phases of the Copahue-Pino Hachado volcanic complex. The primary origin of these materials would be related to the Rahue and Butahuo volcanoes which record the latest eruptions (García-Morabito and Folguera, 2005; Tunstall and Folguera, 2005) and are located only $30 \mathrm{~km}$ to the west of the paleo-Agrio river.

Moreover, during the interuptive phases, the sedimentary record corresponds to the gravelly braided fluvial system of the palaeo-Agrio river. Although some authors consider that these phases represent periods of incision when streams adjust to re-establish their former graded profile (Smith, 1987, 1991; Khalaf, 2012), the preserved depositional morphology of the fluvial facies association is the result of a short- term moderate rate of aggradation, high cannel migration (Bridge and Leeder, 1979; Bristow and Best, 1993) and frequent sheet flooding, combined with a longerterm aggradation rate of the whole fluvial system.

The sheet-like and lobate deposits of the facies Gms, located towards the south of study area were also accumulated during intraeruptive phases. These deposits occur where the Huarenchenque Formation expands to the west in parallel with the main tributaries of the Agrio River (Fig. 1). This suggests that steepland debris flows descending directly from the Andean foothills deposited facies Gms en masse when reaching the lower gradient paleo-Agrio fluvial valley (cf. Lancaster and Casebeer, 2007).

Last but not least, the peculiar model of braided fluvial sedimentation of the Huarenchenque Formation, resembling that of sandur plains, strongly suggests that high discharges of the palaeo-Agrio river and palaeo-tributaries were provided by meltwater due to the rapid Andean Last Glacial Maximum deglaciation (McCulloch et al., 2000; Hulton et al., 2002).

\subsection{Clast composition, provenance and palaeo- hydraulic considerations}

The main components of the intereruptive conglomerates are subrounded to rounded basalt 


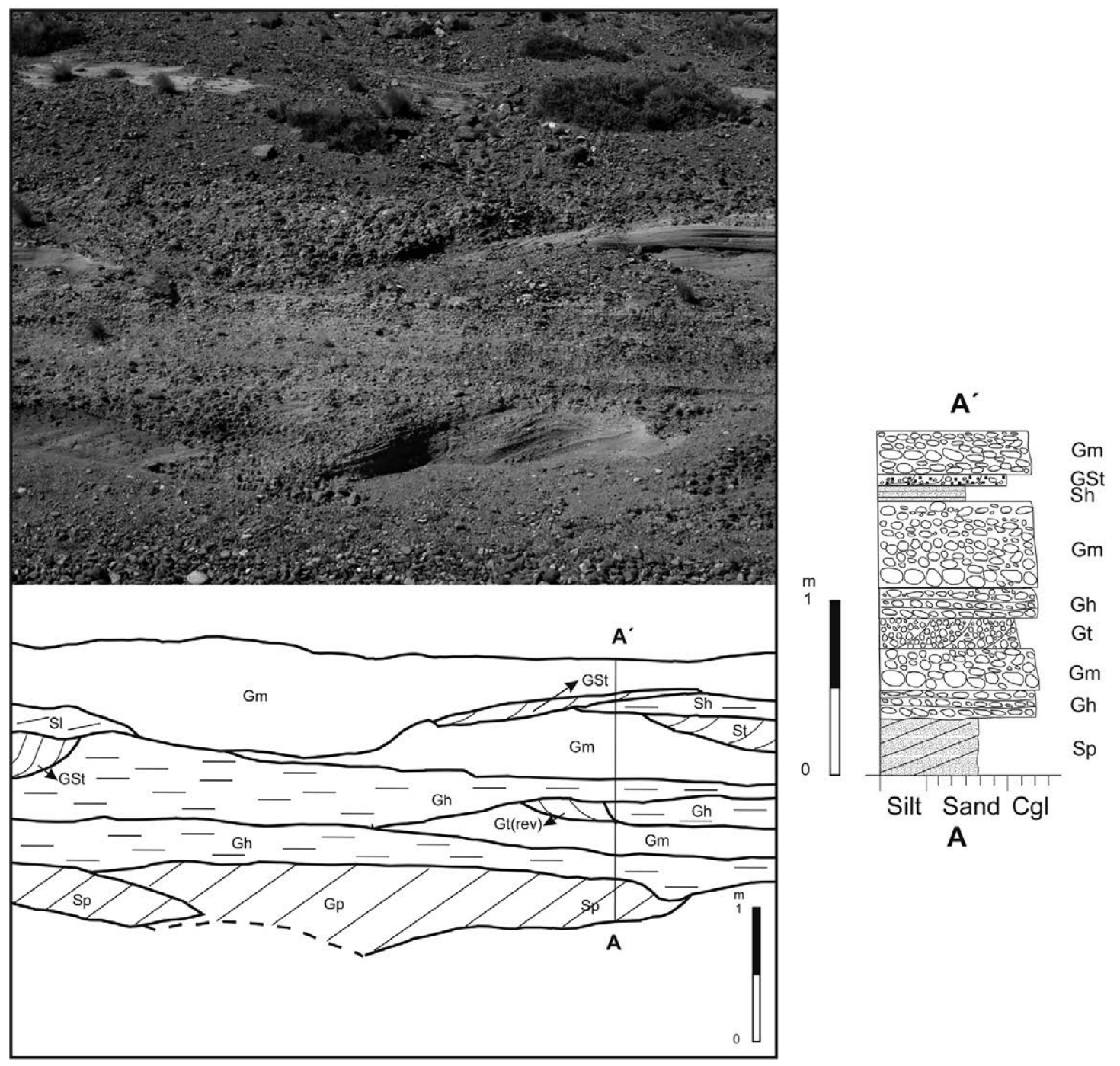

FIG. 10. Example of bedding architecture and facies organization in the fluvial facies association, traced from a photo mosaic at location 2 (see Fig. 1). Facies code in table 1.

fragments with subordinated proportion of granite and other volcanic lithoclasts, representing an extrabasinal input. Intrabasinal clasts (rounded fragments of pumice and hardened mud) provided by erosion of syneruptive deposits and overbanks are scarce due to their weak mechanical resistance under high-regime flows. Clast composition allows to deduce that most of fluvial materials derived from the Andean volcanic arc and from widespread PlioPleistocene alkali olivine basalts erupted across the Andean backarc (Kay et al., 2006).

In contrast, the cross-bedded sandstone sets are commonly basaltic-rich litharenites, although some beds are almost entirely composed of pumice grains. In this last case, transport conditions for fluvial sandstones (dune migration) allowed preservation of intrabasinal components sourced by syneruptive pyroclastic deposits.

Further interpretations arise from the analysis of cross-bedded sandstone sets characterized by the alternations between basaltic-rich and pumice-rich foresets. In a previous work (Colombo et al., 2018), we demonstrated that the low density of pumice clasts was substantially modified when the pyroclastic flows at very high temperatures were placed in a mass of shallow water and steam displaces the air in 

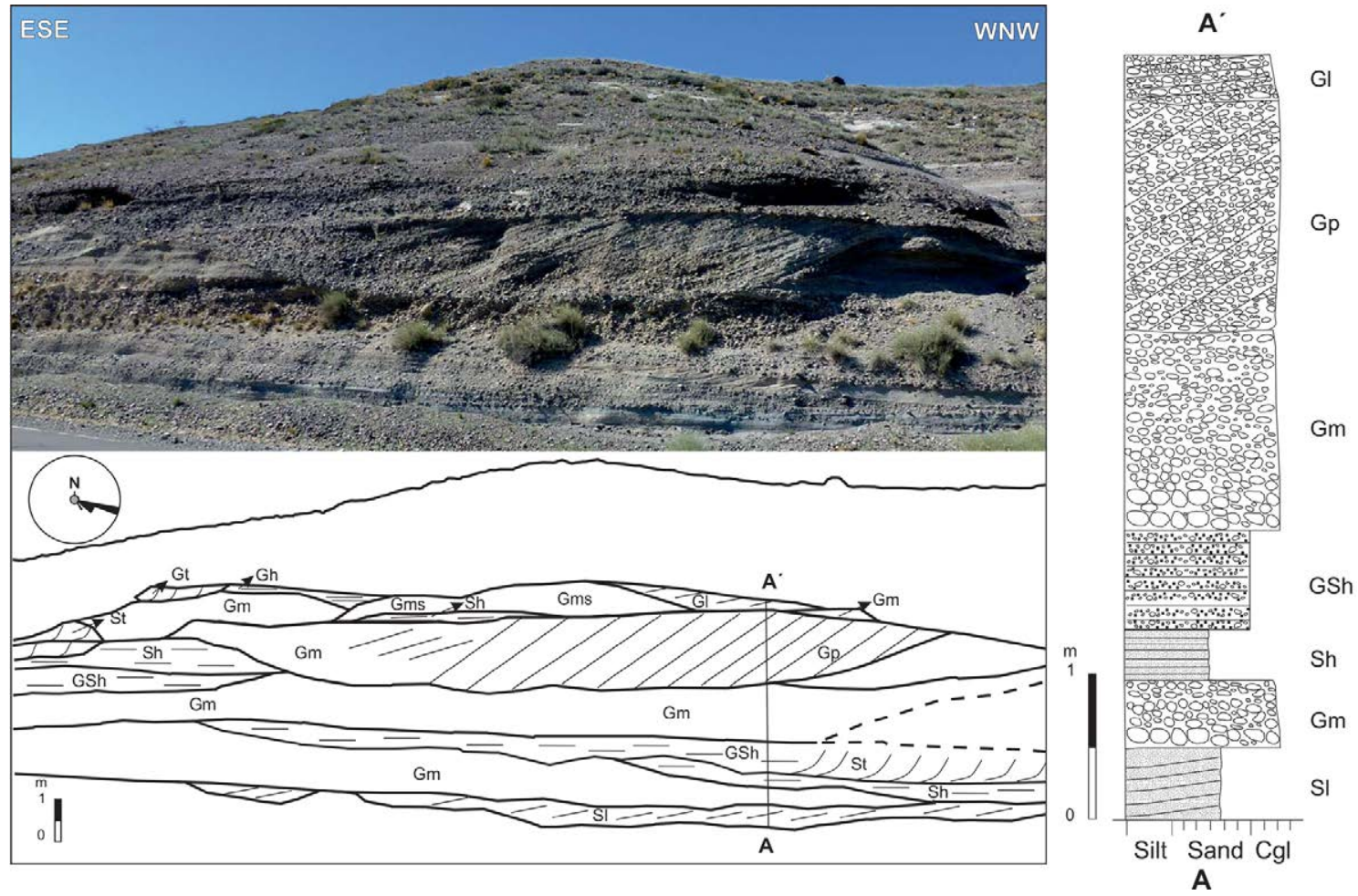

FIG. 11. Fluvial facies association. Photomosaic, bedding architecture, facies organization and palaeocurrents (measured on the foreset dip direction) of cliff face at location 2 (see Fig. 1). Facies code in table 1.

their pores. Therefore steam condensation and water absorption causes pumice clasts to sink. Under these conditions, water saturated pumice clasts tend to behave as "normal" (high-density) clasts, although they still preserve some differences of settling velocity (hydraulic equivalence) with respect to that of the basalt sand grains (Fig. 4B).

A remaining question is why the alternance of basalt-rich and pumice-rich intervals were produced in the foresets of cross-bedded strata. The response could be that frontal accretion of basalt-rich foresets represents the normal condition for fluvial transportation-deposition of extrabasinal materials derived from the denudation of volcanic terranes. Meanwhile, the pumice-rich foresets result from the rework of intrabasinal syneruptive pyroclastic deposits. Thus, the presence of these intervals suggests that: $\mathbf{i}$. the syneruptive events that occupied the paleo-Agrio river valley were more frequent than those displayed in the sedimentary record; ii. these pyroclastic materials were strongly eroded by the fluvial system; and iii. the pumice clasts were probably supplied from coeval pyroclastic activity.

\section{Conclusions}

The main conclusions drawn from this study are as follows:

- The Huarenchenque Formation represent the preserved product of two lithofacies associations (fluvial and pyroclastic).

- Sedimentation occurred in two distinct phases: intereruptive (dominated by fluvial deposits) and syneruptive (essentially composed of pyroclastic deposits).

- The fluvial facies association is composed of polymictic conglomerates with the predominance of basalt-dominated clasts, coarse- medium-grained conglomeratic sandstones and medium- to coarsegrained sandstones.

- Intereruptive fluvial deposits were accumulated in a multichannel fluvial system characterized by high bed load, steep gradient and non-cohesive 
bank materials. High bank full discharge seems to be related to rapid deglaciation of the Andean Last Glacial Maximum.

- The syneruptive pyroclastic facies association is characterized by lapilli and ash tuffs deposited from air fall, pyroclastic density current, and density stratified surge mechanisms. High-explosive episodes of the neighbor Andean strato-volcanoes are considered the trigger mechanisms for these primary pyroclastic deposits.

- Most of the fluvial deposits are rich in basaltic fragments sourced from the Andean arc volcanics and from widespread Plio-Pleistocene backarc olivine basalts. However, several cross-bedded gravelly sandstones and sandstones are composed almost entirely of pumiceous fragments, while others display a marked alternation between "basalt" and "pumiceous" foresets. The participation of these pyroclastic components in typical intereruptive fluvial deposits allows suggest that explosive volcanic events and primary pyroclastic supply could be more frequent than reflected by the pyroclastic (syneruptive) deposits themselves. In addition, the eventual erosion (and even total elimination) of syneruptive pyroclastic deposits by the braided fluvial system should not be ruled out.

\section{Acknowledgements}

The authors thank Andean Geology editor W. Vivallo and A.M. Combina who improved an early version of the manuscript through constructive comments.

\section{References}

Allen, J.R.L. 1982. Sedimentary structures, their character and physical basis; unabridged one-volume edition. Developments in Sedimentology 30, Part A: 593 p. Elsevier. Amsterdam.

Bahk, J.J.; Chough, S.K. 1996. An interplay of syn- and intereruption depositional processes: the lower part of the Jangki Group (Miocene), SE Korea. Sedimentology 43: 421-438.

Branney, M.J.; Kokelaar, P. 2002. Pyroclastic density currents and the sedimentation of ignimbrites. Geological Society, Memoirs 27: 152 p. London.

Bridge, J.S.; Leeder, M.R. 1979. A simulation model of alluvial stratigraphy. Sedimentology 26: 617-644.

Bridge, J.S.; Lunt, I. A. 2005. Depostional models of braided rivers. In Braided Rivers: Process, Deposits, Ecology and Management (Sambrook Smith, G.H.; Best, J.L.;
Bristow, C.S.; Petts, G.E.; editors). Special Publication International Association of Sedimentologists 36: 11-50. Blackwell Publishing Ltd. Oxford.

Bristow, C.S.; Best, J. L. 1993. Braided rivers: perspectives and problems. In Braided Rivers (Best, J.L.; Bristow, C.S.; editors). Geological Society, Special Publication 75: 1-12. London.

Cole, P.D. 1991. Migration direction of sand-wave structures in pyroclastic-surge deposits: implications for depositional processes. Geology 19: 1108-1111.

Cole, R.B.; Ridgway, K.D. 1993.The influence of volcanism on fluvial depositional systems in a Cenozoic strike-slip basin, Denial Fault System, Yukon Territory, Canada. Journal of Sedimentary Petrology 63: 152-166.

Colombo, F.; Bargalló, R.; Spalletti, L.A.; Enrique, P.; Queralt, I. 2018. Pumice clasts in cross-stratified basalt-dominated sandstones and conglomerates. Characteristics and depositional significance: Huarenchenque Fm. (Neuquén, Argentina). Journal of Iberian Geology 45: 29-46.

Edmonds, M.; Herd, R.A. 2005. An inland-directed base surge generated by the explosive interaction of pyroclastic flows and seawater at Soufrière Hills volcano, Montserrat. Geology 33: 245-248.

Fisher, R.V. 1990. Transport and deposition of a pyroclastic surge across an area of high relief: the 18 May 1980 eruption of Mount St. Helens, Washington. Geological Society of America Bulletin 102: 1038-1054.

Galland, O.; Hallot, E.; Cobbold, P.R.; Ruffet, G.; de Bremond d'Ars, J. 2007. Volcanism in a compressional Andean setting: A structural and geochronological study of Tromen volcano (Neuquén province, Argentina). Tectonics 26: 1-24.

García Morabito, E.; Folguera, A. 2005. El alto de Copahue-Pino Hachado y la fosa de Loncopué: un comportamiento tectónico episódico, Andes neuquinos $\left(37^{\circ}-39^{\circ} \mathrm{S}\right)$. Revista de la Asociación Geológica Argentina 60: 742-761.

Gençalioğlu-Kuşcu, G.; Atilla, C.; Cas, R.A.F.; Kuşcu, I. 2007. Base surge deposits, eruption history, and depositional processes of a wet phreatomagmatic volcano in Central Anatolia (Cora Maar). Journal of Volcanology and Geothermal Research 159: 198-209.

Gihm, Y.S.; Hwang, G. 2014. Syneruptive and intereruptive lithofacies in lacustrine environments: The Cretaceous Beolkeum Member, Wido Island, Korea. Journal of Volcanology and Geothermal Research 273: 15-32.

Hildreth, W.; Moorbath, S. 1988. Crustal contributions to arc magmatism in the Andes of central Chile. Contributions to Mineralogy and Petrology 98: 455-489. 
Hulton, N.R.J.; Purves, R.S.; McCulloch, R.D.; Sugden, D.E.; Bentley, M.J. 2002. The last glacial maximum and deglaciation in southern South America. Quaternary Science Reviews 21: 233-241.

Ielpi, A.; Gibling, M.R.; Bashforth, A.R.; Lally, C.; Rygel, M.C.; Al-Silwadi, S. 2014. Role of vegetation in shaping Early Pennsylvanian braided rivers: architecture of the Boss Point Formation, Atlantic Canada. Sedimentology 61: 1659-1700.

Kataoka, K.S.; Manville, V.; Nakajo, T.; Urabe, A. 2009. Impacts of explosive volcanism on distal alluvial sedimentation: examples from the Pliocene-Holocene volcaniclastic successions of Japan. Sedimentary Geology 220: 306-317.

Kay, S.M.; Burns, M.; Copeland, P. 2006. Upper Cretaceous to Holocene Magmatism over the Neuquén basin: evidence for transient shallowing of the subduction zone under the Neuquén Andes ( $36^{\circ} \mathrm{S}$ to $38^{\circ} \mathrm{S}$ latitude). In Late Cretaceous to Recent Magmatism and Tectonism of the Southern Andean Margin at the Latitude of the Neuquén Basin (36-39²) (Kay, S.M.; Ramos, V.A.; editors). Geological Society of America, Special Paper 407: 191-60. Boulder.

Khadkikar, A. 1999. Trough cross-bedded conglomorate facies. Sedimentary Geology 128: 39-49.

Khalaf, E.E.D.A.H. 2012. Mechanisms of volcaniclastic aggradation in fluvial systems influenced by explosive volcanism: An example from Neoproterozoic Hammamat Group, Wadi Queih area, Central Eastern Desert, Egypt. Journal of African Earth Sciences 68: 44-66.

Kuenzi, W.D.; Horst, O.H.; McGehee, R.V. 1979. Effect of volcanic activity on fluvial-deltaic sedimentation on a modern arc-trench gap, southwestern Guatemala. Geological Society of America Bulletin 90: 827-838.

Lancaster, S.T.; Casebeer, N.E. 2007. Sediment storage and evacuation in headwater valleys at the transition between debris-flow and fluvial processes. Geology 35: 1027-1030.

Lang, J.; Dixon, R.J.; Le Heron, D.P.; Winsemann, J. 2012. Depositional architecture and sequence stratigraphic correlation of Upper Ordovician glacigenic deposits, Illizi Basin, Algeria. In Glacigenic Reservoirs and Hydrocarbon Systems (Huuse, M.; Redfern, J.; Le Heron, D.P.; Dixon, R.J.; Moscariello, A.; Craig, J.; editors). Geological Society, Special Publication 368: 293-317. London.

Leanza, H.; Hugo, C.; Repol, D.; González, R.; Danieli, J. 2001. Hoja geológica Zapala, Hoja 3969-I, 1:250.000, Instituto de Geología y Recursos Minerales, Boletín 275: 128 p. Buenos Aires.
Lunt, I. A.; Bridge, J. S.; Tye, R.S., 2004. A quantitative, three- dimensional depositional model of gravelly braided rivers. Sedimentology 51: 377-414

Maizels, J.K. 1993. Lithofacies variations within sandur deposits: the role of runoff regime, flow dynamics and sediment supply characteristic. Sedimentary Geology 85: 299-325.

Major, J.J.; Janda, R.J.; Daag, A.S. 1996. Watershed disturbance and lahars on the east side of Mount Pinatubo during the mid-June 1991 eruptions. In Fire and Mud: Eruptions and Lahars of Mount Pinatubo, Philippines (Newhall, C.G.; Punongbayan, R.S.; editors). Philippine Institute of Volcanology and Seismology, Quezon City and University of Washington Press, Seattle: 895-920.

Manville, V.; Nemeth, K.; Kano, K. 2009. Source to sink: a review of three decades of progress in the understanding of volcaniclastic processes, deposits, and hazards. Sedimentary Geology 220: 136-161.

Mathisen, M.E.; Vondra, C.F. 1983. The fluvial and pyroclastic deposits of the Cagayan Basin, Northern Luzon, Philippines-an example of non-marine volcaniclastic sedimentation in an inter-arc basin. Sedimentology 30: 369-392.

Mazzoni, M. M. 1986. Procesos y depósitos piroclásticos. Asociación Geológica Argentina, Serie B Didáctica y Complementaria 14: 104 p. Buenos Aires.

McCulloch, R.D.; Bentley, M.J.; Purves, R.S.; Hulton, N.R.J.; Sugden, D.E.; Clapperton, C.M. 2000. Climatologic inferences from glacial and palaeoecological evidence at the last glacial termination, southern South America. Journal of Quaternary Science 15: 409-417.

Melnick, D.; Folguera, A.; Ramos, V. 2006. Structural control on arc volcanism: The Caviahue-Copahue complex, Central to Patagonian Andes transition $\left(38^{\circ} \mathrm{S}\right)$. Journal of South American Earth Sciences 22: 66-88.

Miall, A.D. 1977. A review of the braided river depositional environment. Earth Science Reviews 13: 1-62.

Miall, A.D. 1978. Lithofacies types and vertical profile models in braided river deposits: a summary. In Fluvial Sedimentology (Miall, A.D.; editor). Canadian Society of Petroleum Geologists, Memoir 5: 597-604. Calgary.

Miall, A.D. 1985. Architectural-element analysis: a new method of facies analysis applied to fluvial deposits. Earth Science Reviews 22: 261-308.

Muñoz, J.; Stern, C. 1988. The Quaternary volcanic belt of the southern continental margin of South America: Transverse structural and petrochemical variations across the segment between $38^{\circ}$ and $39^{\circ} \mathrm{S}$. Journal of South American Earth Sciences 1: 147-161. 
Németh, K.; Cronin, S.J.; Stewart, R.B.; Charley, D. 2009. Intraand extra-caldera volcaniclastic facies and geomorphic characteristics of a frequently active mafic island-arc volcano, Ambrym Island, Vanuatu. Sedimentary Geology 220: 256-270.

Palmer, B.A. 1997. Sedimentary record of calderaforming eruptions, Eocene Challis volcanic field, Idaho. Geological Society of America Bulletin 109: 242-252.

Palmer, B.A.; Shawkey, E.P. 1997. Lacustrine sedimentation processes and patterns during effusive and explosive volcanism, Challis volcanic field, Idaho. Journal of Sedimentary Research 67: 154-167.

Palmer, B.A.; Purves, A.M.; Donoghue, S.L. 1993. Controls on accumulation of a volcaniclastic fan, Ruapehu composite volcano, New Zealand. Bulletin of Volcanology 55: 176-189.

Pierson, T.C.; Daag, A.S.; De Los Reyes, P.J.; Regalado, M.T.M.; Solidum, R.U.; Tubianosa, B.S., 1996. Flow and deposition of posteruption hot lahars on the east side of Mount Pinatubo, July-October 1991. In Fire and Mud: Eruptions and Lahars of Mount Pinatubo, Philippines (Newhall, C.G.; Punongbayan, R.S.; editors). Philippine Institute of Volcanology and Seismology, Quezon City and University of Washington Press, Seattle: 921-950.

Pierson, T.C.; Pringle, P. T.; Cameron, K.C. 2011. Magnitude and timing of downstream channel aggradation in response to a dome-building eruption at Mount Hood, Oregon. Geological Society of America Bulletin 123: 3-20.

Ramos, 1978. Estructura. In Geología y recursos naturales de la Provincia del Neuquén (Rolleri E.O.; editor). Congreso Geológico Argentino, No. 7, Relatorio: 9-24. Buenos Aires.

Ramos, V.A.; Folguera, A.; García Morabito, E. 2011. Las Provincias Geológicas del Neuquén. In Geología y Recursos Naturales de la Provincia de Neuquén (Leanza, H.; Arregui, C.; Carbone, O.; Danieli, J.C.; Vallés, J.; editores). Congreso Geológico Argentino, No. 18, Asociación Geológica Argentina 27:317-326. Buenos Aires.

Rust, B.R. 1978. A classification of alluvial channel systems. In Fluvial Sedimentology (Miall, A.D.; editor). Canadian Society of Petroleum Geologists, Memoir 5: 187-198. Calgary.

Sambrook Smith, G.H.; Ashworth, P.J.; Best, J.L.; Woodward, J.; Simpson, C.J. 2006. Alluvial architecture of the sandy braided South Saskatchewan River, Canada. Sedimentology 53: 413-434.
Schmincke, H.-U.; Fisher, R.V.; Waters, A.C. 1973. Antidune and chute and pool structures in the base surge deposits of the Laacher See area, Germany. Sedimentology 20: 553-574.

Segschneider, J.; Anderson, D.L.T.; Vialard, J.; Balmaseda, M.; Stockdale, T.N. 2002. Initialization of seasonal forecasts assimilating sea level and temperature observations. Journal of Climate 14: 4292-4307.

Smith, G.A. 1986. Coarse-grained nonmarine volcaniclastic sediment: terminology and depositional process. Geological Society of America Bulletin 97: 1-10.

Smith, G.A. 1987. The influence of explosive volcanism on fluvial sedimentation: the Deschutes Formation (Neogene) in central Oregon. Journal of Sedimentary Petrology 57: 613-629.

Smith, G.A. 1991. Facies sequences and geometries in continental volcaniclastic sequences. In Sedimentation in Volcanic Settings (Fisher, R.V.; Smith, G.A.; editors). Society of Economic Paleontologists and Mineralogists, Special Publication 45: 109-122. Tulsa.

Sohn, Y.K.; Rhee, C.W.; Kim, B.C. 1999. Debris flow and hyperconcentrated flood-flow deposits in an alluvial fan, NW part of the Cretaceous Yongdong Basin, central Korea. Journal of Geology 107: 111-132.

Sohn, Y.K.; Ki, J.S.; Jung, S.; Kim, M.C.; Cho, H.; Son, M. 2013. Synvolcanic and syntectonic sedimentation of the mixed volcaniclastic-epiclastic succession in the Miocene Janggi Basin, SE Korea. Sedimentary Geology 288: 40-59.

Sparks, R.S.J.; Walker, G.P.L. 1973. The ground surge deposit: a third type of pyroclastic rock. Nature 241: 62-64.

Stern, C.R. 2004. Active Andean volcanism: its geologic and tectonic setting. Revista Geológica de Chile 31 (2): 161-206. doi: 10.5027/andgeoV31n2-a01.

Stokes, M.; Griffiths, J.S.; Mather, A. 2012. Palaeoflood estimates of Pleistocene coarse grained river terrace landforms (Río Alzamora, SE Spain). Geomorphology 149: 11-26.

Stura, S.; Mazzoni, M.M. 1994. Facies fluviales volcaniclásticas en terrazas pleistocenas de la Formación Huarenchenque, valle del río Agrio, Neuquén, Argentina. In Reunión Argentina de Sedimentología, No. 5: 171-176. San Miguel de Tucumán.

Teruggi, M.E.; Mazzoni, M.M.; Spalletti, L.A.; Andreis, R.R. 1978. Rocas Piroclásticas. Interpretación y Sistemática. Asociación Geológica Argentina, Serie B, Didáctica y Complementaria 5: 1-33. Buenos Aires.

Tunstall, C.; Folguera, A. 2005. Control estructural en el desarrollo de una concentración anómala de calderas 
en los Andes de Neuquén: Complejo volcánico de Pino Hachado ( $38^{\circ} 30^{\prime} \mathrm{S}$ y $71^{\circ} \mathrm{O}$ ). Revista de la Asociación Geológica Argentina 60: 731-741.

Valentine, G.A.; Palladino, D.M.; Agosta, E.; Taddeucci, J.; Trigila, R. 1998. Volcaniclastic aggradation in a semi-arid environment, northwestern Vulcano Island, Italy.Geological Society of America Bulletin 110: 630-643.

Vázquez, J.A.; Ort, M.H. 2006. Facies variation of eruption units produced by the passage of single pyroclastic surge currents, Hopi Buttes volcanic field, USA. Journal of Volcanology and Geothermal Research 154: 222-236.
Waresback, D.B.; Turbeville, B.N. 1990. Evolution of a Plio-Pleistocene volcanogenic alluvial fan: the Puye Formation, Jemez Mountains, New Mexico. Geological Society of America Bulletin 102: 298-314.

Zanchetta, G.; Sulpizio, R.; Pareschi, M. T.; Leoni, F.M.; Santacroce, R. 2004. Characteristics of May 5-6, 1998 volcaniclastic debris-flows in the Sarno area of Campania, Southern Italy: relationships to structural damage and hazard zonation. Journal of Volcanology and Geothermal Research 133: 377-393.

Zanettini, J.C.M. 1979. Geología de la comarca de Campana Mahuida (Provincia del Neuquén). Revista de la Asociación Geológica Argentina 34: 61-68.

Manuscript received: February 20, 2018; revised/accepted: November 21, 2018; available online: February 04, 2019. 